\title{
Ovulation, fertilization and lambing rates, and peripheral progesterone concentrations, in ewes inseminated at a natural oestrus during November or February
}

\author{
L. M. Mitchell ${ }^{1}$, M. E. King ${ }^{1}$, R. P. Aitken ${ }^{2}$, F. E. Gebbie ${ }^{1}$ and J. M. Wallace ${ }^{2}$ \\ ${ }^{1} S A C$, The Ferguson Building, Craibstone Estate, Bucksburn, Aberdeen AB21 9YA, UK; and ${ }^{2}$ Rowett Research Institute, \\ Greenburn Road, Bucksburn, Aberdeen AB21 9SB, UK
}

\begin{abstract}
The objective of this study was to determine the relative importance of seasonal changes in ovulation rate, fertilization rate and embryo survival as the cause of reduced lambing rates in ewes mated in February compared with those mated in November. The study was conducted at $57^{\circ} \mathrm{N}$ using mature Mule ewes and Suffolk rams. Sixty ewes were allocated equally to five groups: unbred (UB) or mated at a natural oestrus during November $(\mathrm{N})$ or February $(\mathrm{F})$ by natural $(\mathrm{N})$ or cervical artificial $(\mathrm{A})$ insemination. Groups were maintained separately at pasture supplemented with hay. A raddled vasectomized or non-vasectomized ram was present with UB, NN and NA groups from 26 October 1995 to 1 January 1996 and with UB, FN and FA groups from 25 January 1996 to 31 March 1996. Ewes marked by the ram were recorded twice a day, and those in groups NN, NA, FN and FA were inseminated at their second behavioural oestrus. For all ewes, blood samples were obtained once a day from introduction of the vasectomized rams until 30 days after mating (groups NN, NA, FN and FA) or 20 days after the first oestrus (group UB), and ovulation rate was measured by laparoscopy 7 days after the first oestrus. For ewes in groups NN, NA, FN and FA, ovulation rate was measured again after the second oestrus and ova were recovered from six ewes per group for assessment of fertilization before autotransfer. Pregnancy and lambing rates were recorded at term. Mean $( \pm \mathrm{SE}$ ) dates of the first recorded oestrus for ewes in groups NN, NA and UB, and FN, FA and UB were $4 \pm 1.1$ November and $4 \pm 0.9$ February, respectively, and intervals between the first and second oestrus were $16 \pm 0.2$ and $17 \pm$ 0.3 days $(P<0.01)$, respectively. Ovulation rates were $2.6 \pm 0.08$ and $2.0 \pm 0.05(P<$ $0.001)$, and peripheral progesterone concentrations during the luteal phase were $8.5 \pm$ 0.25 and $7.6 \pm 0.31 \mathrm{ng} \mathrm{ml}^{-1}(P<0.05)$, for November and February, respectively. The difference in peripheral progesterone concentration was not solely attributable to the difference in ovulation rate. There was no significant effect of month or method of insemination, or of embryo recovery and autotransfer procedures on pregnancy rates and the proportion of ewes that became pregnant were NN 0.92, NA 0.83, FN 0.67 and FA 0.75 . For ewes undergoing embryo recovery and autotransfer, ova recovered per corpus luteum were $1.00,0.93,1.00$ and 0.92 , fertilized ova per ovum recovered were $0.69,0.92,1.00$ and 0.83 , and lambs born per corpus luteum were $0.62,0.79,0.78$ and 0.58 for NN, NA, FN and FA groups, respectively. There were no significant seasonal effects on fertilization rate or embryo survival. It is concluded that a seasonal decline in ovulation rate is the primary cause of reduced lambing rates in ewes mated in February compared with those mated in November. Pregnancy rates were high after mating in both periods and were not enhanced by the use of cervical insemination.
\end{abstract}

\section{Introduction}

Seasonal breeding is a survival strategy adopted by many wild mammals to ensure that their offspring are born at the most favourable time of the year. In sheep, which have been domesticated for almost 10000 years, a seasonal pattern of

Received 30 March 1998. reproductive activity and quiescence persists, as evidenced by distinct breeding and non-breeding periods in ewes and circannual changes in libido, testicle size and semen characteristics in rams.

The seasonal pattern of reproduction represents an endogenous rhythm that is entrained by environmental factors. Of these, photoperiod is of greatest importance in 
temperate regions in which ewes must be exposed to both the lengthening days of spring and the decreasing daylength after the summer solstice for a breeding season of normal onset and duration (Malpaux et al., 1989; Malpaux and Karsch, 1990). The timing of reproductive transitions is influenced by genotype (Wheeler and Land, 1977), and the breeding season invariably includes the shortest day (Hammond, 1944). Both nutrition (Rhind, 1992) and photoperiod (Karsch et al., 1984) can influence fecundity within the breeding season via direct effects on the activity of the hypothalamic-pituitary-ovarian axis.

The breeding season of Mule (Bluefaced Leicester $x$ Scottish Blackface) ewes at $57^{\circ} \mathrm{N}$ extends from September to April, and ewes have up to 16 ovarian cycles (Mitchell et al., 1997). However, lambing rates are reduced when mating takes place after the winter solstice (Mitchell et al., 1996, 1997). Possible causes of this include: (i) a seasonal decline in ovulation rate that is not solely attributable to seasonal changes in nutrition; (ii) a reduction in fertilization rate as a consequence of sub-optimal mating activity; and (iii) seasonal alterations in circulating hormone concentrations, especially progesterone which is required to support early pregnancy.

The objective of the present study was to determine the relative importance of seasonal changes in ovulation rate, fertilization rate and embryo survival as the cause of reduced lambing rates in Mule ewes mated during the latter part of their natural breeding season. The Mule is a popular cross in Britain and this study is highly relevant to the increasing number of commercial sheep producers who are adopting late lambing systems and are experiencing, on average, a $20 \%$ reduction in the number of lambs born (Vipond, 1997).

\section{Materials and Methods}

\section{Animals and experimental design}

The study was conducted at $57^{\circ} \mathrm{N}$ using mature Mule ewes and Suffolk rams. Animals were maintained at pasture and were supplemented with hay as necessary to prevent body condition loss. Ewe body condition score was assessed (Russel et al., 1969) at initial allocation to treatment groups in October and at 1 month intervals thereafter.

The design of the main experiment was a $2 \times 2$ factorial with 12 ewes per treatment. Within this design, ewes were mated during November $(\mathrm{N})$ or February $(\mathrm{F})$ by natural $(\mathrm{N})$ or cervical artificial (A) insemination. In addition to the mated groups, there was an unbred group (UB) of 12 ewes that were monitored throughout one natural oestrous cycle in both November and February to determine seasonal changes in ovulation rate and circulating hormone concentrations within the same animals, independent of pregnancy effects.

Raddled vasectomized rams were introduced to groups NN, NA and UB on 26 October and to groups FN, FA and UB on 25 January, and were used to detect an initial behavioural oestrus. Ewes marked by the rams were recorded twice a day. After 17 days, the vasectomized ram with groups NN and FN was replaced by a raddled non-vasectomized ram, observation and recording of marked ewes continued, and ewes in mated groups were naturally or artificially inseminated at their second behavioural oestrus. Cervical artificial insemination (Evans and Maxwell, 1987) of ewes in groups NA and FA was carried out using $0.2 \mathrm{ml}$ fresh undiluted semen, collected by artificial vagina from a single second ram, at the time of the second oestrus and again after 12 and $24 \mathrm{~h}$.

\section{Blood sampling}

Blood samples were obtained once a day from all ewes by jugular venepuncture (Vacutainer, Becton-Dickinson Limited, Coventry) for determination of the peripheral progesterone concentration. Sampling commenced at the time the vasectomized rams were introduced and continued until 30 days after insemination for ewes in groups NN, NA, FN and FA, and until 20 days after the first oestrus for ewes in the UB group.

In addition, eight ewes from the UB group were fitted with an indwelling jugular catheter (Intraflon 2 i.v.; Vycon, Ecouen) on day 10 after their first recorded oestrus in November and again in February. Blood samples were withdrawn at $15 \mathrm{~min}$ intervals for $8 \mathrm{~h}$ for the measurement of pulsatile LH secretion.

\section{Measurement of ovulation, fertilization and lambing rates}

Ovulation rate was measured by laparoscopic viewing of the ovaries and counting of corpora lutea (Boyd and Ducker, 1973) in all ewes 7 days after their first recorded oestrus. After the second oestrus (insemination), laparoscopy was carried out on six ewes in each of the NN, NA, FN and FA groups. The remaining ewes in these groups underwent recovery of ova and autotransfer procedures on day 4 after insemination for the additional determination of fertilization rate. For laparoscopy, ewes were sedated by injection of $0.6 \mathrm{ml}$ acepromazine maleate BP i.m. (ACP injection, $10 \mathrm{mg} \mathrm{ml}^{-1}$; CVet Limited, Bury St Edmunds), and local anaesthesia at trochar and cannula entry sites was achieved by injection of $10 \mathrm{ml}$ lignocaine hydrochloride BP and adrenaline BP s.c. (Lignol; Arnolds Veterinary Products, Shrewsbury). For ovum recovery and autotransfer, ewes were anaesthetized by inhalation of a mixture of halothane, nitrous oxide and oxygen and ova were recovered by retrograde flushing of each oviduct (Hunter $e t$ al., 1955) using ovum culture medium (ICN Biomedicals Limited, Thame). Fertilization rate and early development were assessed using a stereomicroscope ( $\times 40$ magnification) and ova were returned to the uterus within $10 \mathrm{~min}$ of recovery. The pregnancy rate and outcome of ewes in mated groups were determined at term. Experimental protocols and animal care were approved by the institute's Animal Care and Use Committee.

\section{Radioimmunoassay}

Progesterone concentrations were measured in duplicate $100 \mathrm{ml}$ aliquots of plasma after radioimmunoassay, as 
described by McNeilly and Fraser (1987). Inter- and intraassay coefficients of variation for low, medium and high quality controls were 18.3 and $15.6 \%, 12.1$ and $8.9 \%$, and 10.5 and $7.7 \%$, respectively. The detection limit was $0.64 \mathrm{ng} \mathrm{ml}^{-1}$.

LH concentrations were measured in duplicate $50 \mu \mathrm{l}$ aliquots of plasma after radioimmunoassay using the modified method of Niswender et al. (1969). The ovine LH antigen used was NIDDK-oLH-1-2(AFP-7071B) and the ovine LH anti-serum used was rabbit NIDDK-anti-oLH1(AFP-192279). Inter- and intra-assay coefficients of variation for low, medium and high quality controls were 9.2 and $8.7 \%$, 7.1 and $6.2 \%$, and 7.2 and $5.5 \%$, respectively. The detection limit was $1.00 \mathrm{ng} \mathrm{ml}^{-1}$.

\section{Definitions}

Periovulatory and luteal progesterone concentrations were calculated for the first ovarian cycle in all ewes, and for the second ovarian cycle in mated ewes. Periovulatory progesterone concentrations were calculated as the mean of the values on the day of oestrus and the day after oestrus, while luteal progesterone concentrations were calculated as the mean of the values between days 8 and 12 after oestrus. $\mathrm{T}_{50}$ was calculated as the time taken to achieve $50 \%$ of the mean luteal progesterone concentration. For mated ewes, there was no significant difference in progesterone concentrations or in $T_{50}$ values between the first and second ovarian cycle, and data for these cycles were pooled in the analysis of seasonal effects on progesterone.

The criteria used to define an LH peak were of Backstrom et al. (1982). An LH peak was identified if (i) the concentration of LH in two consecutive samples ('peak samples') was higher than the mean of the two previous samples; and (ii) the difference for at least one of the peak samples was greater than four times the intra-assay coefficient of variation. The amplitude of the LH peak was defined as the difference between the highest $\mathrm{LH}$ value in the peak and the mean of the previous two baseline samples.

\section{Statistical analyses}

Data pertaining to ewe body condition scores, interoestrous intervals and peripheral hormone concentrations were analysed by analysis of variance (General Linear Model, MINITAB 11.12; Minitab Inc., USA). Data for ovulation rates were analysed using the Kruskal-Wallis nonparametric rank test. The chi squared test was used for analysis of pregnancy rates.

\section{Results}

\section{Ewe body condition score}

The winter during which the study was conducted was relatively cold with snow falls in every month except October. As a consequence, the availability of pasture was limited and ewes were reliant on supplementary hay as a feed. Ewe body condition scores were maintained throughout the study and did not differ significantly among treatment groups. Overall mean $( \pm S E)$ scores for ewes monitored from October to December (groups NN, NA and UB), and from January to March (groups FN, FA and UB) were $3.0 \pm 0.06$ and $2.9 \pm 0.06$, respectively.

\section{Oestrus and ovulation}

All ewes monitored from October to December showed oestrous behaviour and had cyclic ovarian activity, as determined from peripheral progesterone concentrations. However, by January, one ewe in the UB group had become anoestrus, and peripheral progesterone concentrations in this ewe remained undetectable throughout the second study period. For reproductively active ewes in groups NN, NA, UB and FN, FA, UB, the overall mean ( $\pm \mathrm{SE}$ ) dates of the first recorded oestrus were $4 \pm 1.1$ November and $4 \pm 0.9$ February, and the intervals between the first and second oestrus were $16 \pm 0.2$ and $17 \pm 0.3$ days, respectively.

Within each study period, there were no significant differences in ovulation rate among treatment groups, or between the first and second ovarian cycle in mated ewes (Fig. 1). However, between study periods, there was a highly significant difference in ovulation rate, with overall means $( \pm \mathrm{SE}$ ) of $2.6 \pm 0.08$ and $2.0 \pm 0.05$ corpora lutea per ewe examined $(P<0.001)$ for November and February, respectively.

\section{Peripheral progesterone concentrations}

Peripheral progesterone concentrations increased more slowly and achieved lower luteal values after ovulation in February compared with November (Table 1). These differences were not solely attributable to the observed seasonal difference in ovulation rate, as shown by comparison of the average progesterone concentration in ovarian cycles associated with two corpora lutea (Fig. 2).

\section{Pulsatile LH secretion}

The number of LH pulses recorded during the midluteal phase of UB ewes monitored in November and February ranged from zero to two per ewe, with a total of six pulses recorded for the eight ewes sampled in each study period. Mean ( \pm SE) LH concentrations were $1.5 \pm 0.06$ and $1.8 \pm$ $0.09 \mathrm{ng} \mathrm{ml}^{-1}(P<0.05)$, and LH pulse amplitudes were $1.0 \pm$ 0.26 and $1.0 \pm 0.39 \mathrm{ng} \mathrm{ml}^{-1}$, for November and February, respectively.

\section{Pregnancy rate and outcome}

Ewes in groups NN, NA, FN and FA, were mated to mature Suffolk rams, with the same rams being used for natural and artificial insemination treatments during November and February. For the ram used for artificial 
Table 1. Mean ( \pm SE) periovulatory and luteal progesterone concentrations, and $\mathrm{T}_{50}$, during ovarian cycles in unmated and mated ewes during November and February

\begin{tabular}{lccc}
\hline & November & February & Significance \\
\hline All ewes, all cycles & $n=54$ & $n=54$ & \\
Periovulatory progesterone $\left(\mathrm{ng} \mathrm{ml}^{-1}\right)$ & $0.9 \pm 0.04$ & $0.8 \pm 0.05$ & $\mathrm{~ns}$ \\
Luteal progesterone $\left(\mathrm{ng} \mathrm{ml}^{-1}\right)$ & $8.5 \pm 0.25$ & $7.6 \pm 0.31$ & $P<0.05$ \\
$\mathrm{~T}_{50}$ (days) & $4.1 \pm 0.10$ & $4.5 \pm 0.13$ & $n .05$ \\
& $n=11$ & $n=9$ & $\mathrm{~ns}$ \\
Unmated ewes & $0.8 \pm 0.06$ & $0.7 \pm 0.04$ & $\mathrm{~ns}$ \\
Periovulatory progesterone $\left(\mathrm{ng} \mathrm{ml}^{-1}\right)$ & $7.7 \pm 0.90$ & $6.5 \pm 0.46$ & $\mathrm{~ns}$ \\
Luteal progesterone $\left(\mathrm{ng} \mathrm{ml}^{-1}\right)$ & $4.0 \pm 0.23$ & $4.2 \pm 0.22$ & \\
$\mathrm{~T}_{50}$ (days) & & & \\
\hline
\end{tabular}

$\mathrm{T}_{50^{\prime}}$ the time taken to achieve $50 \%$ of the mean luteal progesterone concentration. ns, not significant.

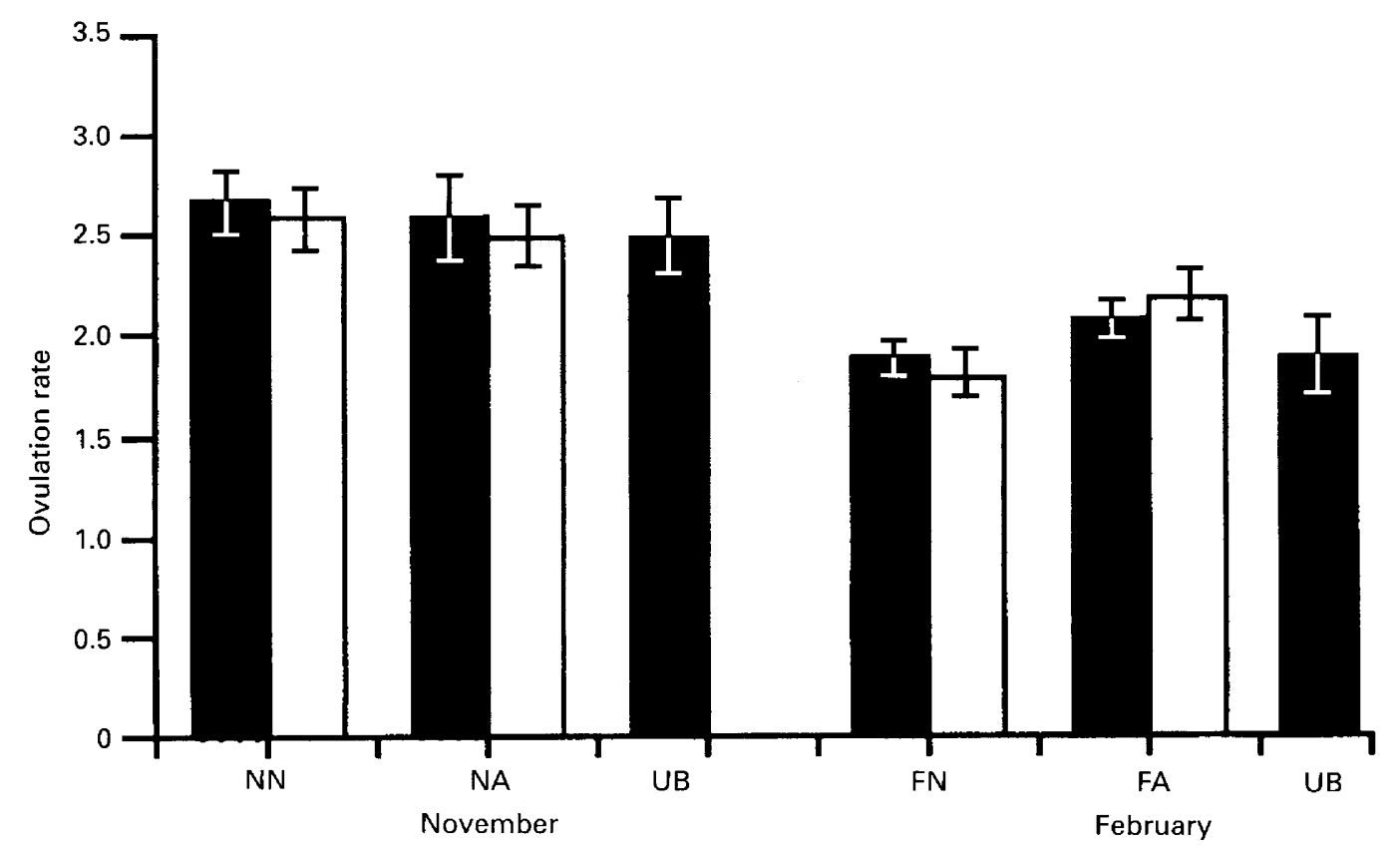

Fig. 1. Mean ( \pm SE) ovulation rates for unbred ewes (UB) and ewes mated during November (N) or February (F) by natural (N) or artificial (A) insemination. $\mathbf{Q}$, first ovarian cycle; $\square$, second ovarian cycle. November versus February, $P<0.001$.

insemination, the ejaculate volume was significantly greater in November than in February $(1.1 \pm 0.09 \mathrm{ml}(n=23)$ versus $0.4 \pm 0.04 \mathrm{ml}(n=25) ; \quad P<0.001)$, but visually assessed motility of spermatozoa did not differ between mating periods. Motility scores on a five-point scale $(1$, non-motile; 5 , rapid wave motion) were $4.5 \pm 0.13$ and $4.5 \pm 0.11$ for November and February, respectively.

There was no significant effect of month or method of insemination, or of embryo recovery and autotransfer procedures on the number of ewes lambing or on the number of lambs born per corpus luteum in pregnant ewes. However, the number of lambs born per ewe inseminated was significantly lower in February as a result of the significant seasonal decline in ovulation rate (Table 2). Three ewes failed to establish pregnancy after mating in November and, according to progesterone data, these animals subsequently ovulated within 17 days. Six ewes failed to establish pregnancy after mating in February and of these, only two had a delay in the subsequent ovulation.

\section{Fertilization and lambing rates in ewes undergoing embryo recovery and autotransfer}

The majority of ova recovered from ewes undergoing embryo recovery and autotransfer procedures were fertilized and resulted in the birth of viable offspring. For ewes in groups NN, NA, FN and FA, the number of ova recovered per corpus luteum was 1.00, 0.93, 1.00 and 0.92; the number of fertilized ova per ova recovered was $0.69,0.92,1.00$ and 0.83 ; and the number of lambs born per corpus luteum was $0.62,0.79,0.78$ and 0.58 , respectively. Unfertilized ova were 
Table 2. Ovulation, pregnancy and lambing rates in ewes mated during November or February by natural $(N)$ or artificial $(A)$ insemination

\begin{tabular}{|c|c|c|c|c|c|}
\hline & \multicolumn{2}{|c|}{ November } & \multicolumn{2}{|c|}{ February } & \multirow{2}{*}{$\begin{array}{c}\text { Significance } \\
\text { (November } \\
\text { versus February) }\end{array}$} \\
\hline & $\mathrm{N}$ & A & $\mathrm{N}$ & A & \\
\hline Number of ewes inseminated & 12 & 12 & 12 & 12 & - \\
\hline Number of pregnant ewes & 11 & 10 & 8 & 9 & ns \\
\hline Number of corpora lutea per inseminated ewe & 2.50 & 2.50 & 1.83 & 2.17 & $P<0.01$ \\
\hline Number of corpora lutea per pregnant ewe & 2.45 & 2.50 & 1.75 & 2.11 & $P<0.05$ \\
\hline Number of lambs born per ewe inseminated & 1.83 & 1.75 & 1.17 & 1.25 & $P<0.01$ \\
\hline Number of lambs born per pregnant ewe & 2.00 & 2.10 & 1.75 & 1.67 & $P<0.01$ \\
\hline $\begin{array}{l}\text { Number of lambs born per corpus luteum in } \\
\text { pregnant ewes }\end{array}$ & 0.81 & 0.84 & 1.00 & 0.79 & ns \\
\hline
\end{tabular}

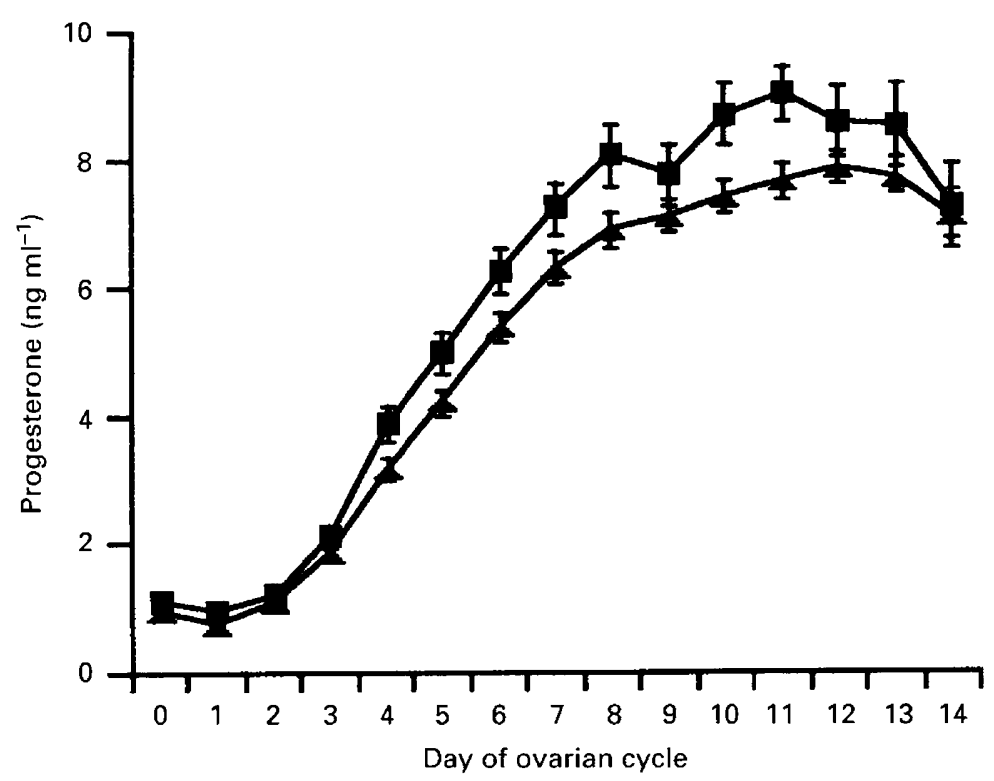

Fig. 2. Mean ( \pm SE) peripheral progesterone concentrations in ewes with two corpora lutea during November $(\boldsymbol{\square}, n=23)$ or February $(\boldsymbol{\Lambda}, n=50)$; day 0 , oestrus.

only recovered from one ewe that was mated naturally during November and thus fertilization failure did not contribute to reduced lambing rates in ewes mated in February.

\section{Discussion}

The breeding season of Mule ewes at $57^{\circ} \mathrm{N}$ extends from September to April (Mitchell et al., 1997). In the present study, inter-oestrous intervals were increased, and ovulation rates were reduced during the latter part of this period. Fertilization rates and embryo survival were not significantly different for ewes mated in February compared with those mated in November, despite a significant seasonal reduction in peripheral progesterone concentrations. The principal cause of reduced lambing rates in ewes mated in February was the reduction in ovulation rate.

Seasonal changes in ovulation rate that are attributable to the direct effects of photoperiod have been reported in ewes (Scaramuzzi and Radford, 1983; Montgomery et al., 1988). Indeed, ovulation rate is reduced by 0.4 corpora lutea per ewe in February compared with November in ewes housed under natural photoperiod and maintained on a constant diet (Mitchell et al., 1996). The effects of nutrition on ovulation rate are well documented (Monget and Martin, 1997), and seasonal changes in pasture availability and quality may have contributed to the reduction in ovulation 
rate in the present study. However, the effect of nutrition is likely to have been small as ewe body condition scores were maintained throughout the study, and supplementary hay made a significant contribution to nutrient intake.

Changes in the activity of the hypothalamic-pituitaryovarian axis induced by photoperiod may influence ovulation rate via alterations in the rate of ovarian follicle development and the viability of gonadotrophin-dependent follicles (Scaramuzzi et al., 1993). Evidence for circannual variations in the rate of follicle development in ewes is equivocal. McNeilly et al. (1991) considered that follicle growth was a continuum, with no significant differences among breeds or seasons, while McNatty et al. (1984) reported that the end of the breeding season in Romney ewes coincided with a period of reduced ovarian activity. If this is the case, then a seasonal reduction in follicular growth rates may have contributed to the reduction in ovulation rate in the present study.

The viability of gonadotrophin-dependent follicles is determined by their individual requirements for FSH, their ability to switch to LH for gonadotrophic support, and the sensitivity of the hypothalamus-pituitary to the positive and negative effects of oestrogen. Autocrine and paracrine mechanisms that protect follicles from atresia are only temporary and, in the absence of an LH surge, these mechanisms eventually fail (Scaramuzzi et al., 1993). The reduction in ovulation rate observed in the present study may have been caused by an increase in the incidence of late atresia in the population of preovulatory follicles as a consequence of a delay in the LH surge. The interval from luteolysis to the $\mathrm{LH}$ surge is determined by luteal progesterone concentrations, the rate of decline of these progesterone concentrations (Haresign, 1985), and the concentration of oestrogen that is subsequently achieved (Joseph et al., 1994, 1995). A threshold concentration of oestrogen is required to initiate the surge and this may be increased during the latter part of the breeding season (Fletcher and Lindsay, 1971). In the present study, lower luteal progesterone concentrations during February may have retarded follicular maturation and steroidogenesis (Hunter et al., 1986; Hunter and Southee, 1987). This, together with the increasing sensitivity of the hypothalamus-pituitary to the inhibitory effects of oestrogen (Webster and Haresign, 1983), may have extended the interval from luteolysis to the LH surge, prolonging the period in which large antral follicles were critically dependent on FSH for gonadotrophic support (Campbell et al., 1995).

Oestrous behaviour is coincident with the LH surge (Fabre-Nys and Martin, 1991), and the increase in interoestrous interval from 16 days in November to 17 days in February observed in the present study supports the possibility of an extended follicular phase. However, Zarco et al. (1988) considered that the follicular phase in ewes is relatively constant, and that variations in cycle duration occur as a consequence of alterations in the timing of luteolysis. The mechanisms that control the timing of the first release of $\mathrm{PGF}_{2 \alpha}$ are not known, but evidence suggests that the uterus must be exposed to progesterone for a fixed period of time. If this is the case, then the more gradual increase in peripheral progesterone concentrations in February compared with November could have delayed luteolysis and increased the inter-oestrous interval by extending the luteal phase. The sampling regimen used in this study did not allow accurate determination of the relative durations of the luteal and follicular phases, and an extension of either or both could have contributed to the increase in inter-oestrous interval.

Increasing sensitivity of the hypothalamus-pituitary to the inhibitory effects of oestrogen during the latter part of the breeding season has been demonstrated by an increase in LH interpulse interval in ovariectomized oestrogen-implanted ewes (Robinson et al., 1985; Joseph et al., 1992). Currie et al. (1993) also reported an increase in LH interpulse interval during the midluteal phase of naturally cyclic ewes in February compared with October and December. In the present study, an insufficient number of LH pulses were recorded to allow accurate determination of the interval between LH pulses, but the increase in LH concentration and the unchanged pulse amplitude during February suggest that the interval between LH pulses may have been decreased at this time. The negative feedback control of pulsatile LH secretion during the breeding season involves the combined actions of oestradiol and progesterone, while the transition to anoestrus is characterized by a profound and qualitative increase in the inhibitory effects of oestrogen alone (Robinson et al., 1985; Karsh, 1987). In the study of Currie et al. (1993), it is likely that ewes monitored during February were in this transitional phase (Jeffcoate et al., 1984) and that the observed increase in the interval between LH pulses in the midluteal phase represents a significant increase in the inhibitory effect of oestrogen from developing ovarian follicles on the hypothalamus and pituitary. In contrast, in the present study, ewes were 1-2 months from the end of their breeding season (Mitchell et al., 1997) and reduced luteal progesterone concentrations at this time may have allowed a slight increase in pulsatile $\mathrm{LH}$ secretion in the absence of a significant increase in the inhibitory effects of oestradiol.

In the present study, fertilization rates were high and pregnancy rates were not improved by the use of cervical artificial insemination. Fertilization rates may be reduced during the latter part of the natural breeding season as a consequence of sub-optimal mating activity in individual rams (Colas, 1983) or adverse environmental and nutritional conditions (Mitchell et al., 1996). However, the rams used in the present study were of proven working ability and produced semen of good quality throughout. Ewes were not severely challenged by environmental or nutritional conditions, as evidenced by their ability to maintain body condition score.

Nine ewes failed to establish pregnancy and of these, only two had a delay in the subsequent ovulation. Therefore, failure to establish pregnancy appears to have been primarily due to fertilization failure or early embryo loss before maternal recognition. The incidence of these problems did not differ between seasons despite the observed difference in circulating progesterone concentrations. Progesterone is important for the histotrophic nutrition of the early embryo (Ashworth, 1995) and suppression of the luteolytic mechanism (Lamming and Mann, 1995). A 
seasonal reduction in peripheral progesterone concentration has been associated with a reduction in embryo survival in ewes mated on four successive occasions during the breeding season (Ashworth et al., 1989). However, in this latter study, fertilization failure or the cumulative effect of experimental procedures to terminate pregnancy may also have been contributory factors. In the present study, in which ewes were mated on only one occasion to fertility tested rams, no such reduction in embryo survival was apparent. It is concluded that a seasonal decline in ovulation rate is the primary cause of reduced lambing rates in ewes mated in February compared with those mated in November.

The authors are grateful to the Scottish Office Agriculture, Environment and Fisheries Department for financial support for this project and wish to thank G. MacClean, K. Fryers, J. Rae and S. Robertson for their technical assistance. The ovine LH antigen and the ovine LH antiserum were gifts from A. F. Parlow, Pituitary Hormones and Antisera Centre, Torrance, California, USA, and the donkey anti-rabbit $\mathrm{IgG}$ and normal rabbit serum were gifts from the Scottish Antibody Production Unit, Law Hospital, Carluke, Lanarkshire, Scotland.

\section{References}

Ashworth CJ (1995) Maternal and conceptus factors affecting histotrophic nutrition and survival of embryos Livestock Production Science 44 99-105

Ashworth CJ, Sales DI and Wilmut I (1989) Evidence of an association between the survival of embryos and the periovulatory plasma progesterone concentration in the ewe Journal of Reproduction and Fertility $\mathbf{8 7}$ 23-32

Backstrom CT, McNeilly AS, Leask RM and Baird DT (1982) Pulsatile secretion of LH, FSH, prolactin, oestradiol and progesterone during the menstrual cycle Clinical Endocrinology 17 29-42

Boyd JS and Ducker MJ (1973) A method of examining the cyclic changes occurring in the sheep ovary using endoscopy Veterinary Record $9040-43$

Campbell BK, Scaramuzzi RJ and Webb R (1995) Control of antral follicle development and selection in sheep and cattle Journal of Reproduction and Fertility Supplement $\mathbf{4 9} 335-350$

Colas G (1983) Factors affecting the quality of ram semen. In Sheep Production pp 453-465 Ed. W Haresign. Butterworths, London

Currie WD, Medhamurthy RJ, Cook SJ and Rawlings NC (1993) Seasonal fluctuation in diurnal rhythms of luteinising hormone secretion in ewes during the mid-luteal phase of the oestrous cycle Journal of Reproduction and Fertility 97 71-74

Evans G and Maxwell WMC (1987) Salamons Artificial Insemination of Sheep and Goats pp 142-166 Butterworths, London

Fabre-Nys C and Martin GB (1991) Hormonal control of proceptive and receptive sexual behaviour and the preovulatory $\mathrm{LH}$ surge in the ewe: reassessment of the respective roles of estradiol, testosterone and progesterone Hormones and Behaviour 25 295-312

Fletcher IC and Lindsay DR (1971) Effect of oestrogen on oestrous behaviour and its variation with season in the ewe Journal of Endocrinology 50 685-696

Hammond J, Jr (1944) On the breeding season in the sheep Journal of Agricultural Science, Cambridge 34 97-105

Haresign W (1985) Comparison of the rate of decline in plasma progesterone concentrations at a natural and progesterone-synchronized oestrus and its effect on tonic $\mathrm{LH}$ secretion in the ewe Journal of Reproduction and Fertility 75 231-236

Hunter GL, Adams CE and Rowson LEA (1955) Interbreed ovum transfer in sheep Iournal of Agricultural Science Cambridge 46 143-149

Hunter MG and Southee JA (1987) Treatment with progesterone affects follicular steroidogenesis in anoestrous ewes Animal Reproduction Science 14 273-279

Hunter MG, Southee JA, McLeod BJ and Haresign W (1986) Progesterone pretreatment has a direct effect on $\mathrm{GnRH}$-induced preovulatory follicles to determine their ability to develop into normal corpora lutea in anoestrous ewes fournal of Reproduction and Fertility 76 349-363
Jeffcoate IA, Rawlings NC and Howell WE (1984) Duration of the breeding season and response to reproductive manipulation in five breeds of sheep under northern prarie conditions Theriogenology 22 279-290

Joseph IBJK, Currie WD and Rawlings NC (1992) Effects of time after ovariectomy, season and oestradiol on luteinizing hormone and folliclestimulating hormone secretion in ovariectomized ewes fournal of Reproduction and Fertility 94 511-523

Joseph IBJK, Ravindra JP and Rawlings NC (1995) Oestradiol and the preovulatory surges of luteinising hormone and follicle stimulating hormone in ewes during the breeding season and transition into anoestrus Animal Reproduction Science $40291-298$

Joseph IBJK, Currie WD, Ravindra JP, Cook SJ and Rawlings NC (1994) Oestradiol and the surge release of gonadotrophins in the ewe Animal Reproduction Science 34 217-230

Karsch FJ (1987) Central actions of ovarian steroids in the feedback regulation of pulsatile secretion of luteinizing hormone Annual Reviews of Physiology 49 365-382

Karsch FJ, Bittman EL, Foster DL, Goodman RL, Legan SJ and Robinson JE (1984) Neuroendocrine basis of seasonal reproduction Recent Progress in Hormone Research 40 185-231

Lamming GE and Mann GE (1995) A dual role for progesterone in the control of cyclicity in ruminants Journal of Reproduction and Fertility Supplement 49 $561-566$

Malpaux B and Karsch FJ (1990) A role for short days in sustaining seasonal reproductive activity in the ewe Journal of Reproduction and Fertility 90 $555-562$

Malpaux B, Robinson JE, Wayne NL and Karsch FJ (1989) Regulation of the onset of the breeding season of the ewe: importance of long days and of an endogenous reproductive rhythm Journal of Endocrinology 122 269-278

McNatty KP, Hudson NL, Henderson KM, Lun S, Heath DA, Gibb M, Ball K, McDiarmid JM and Thurley DC (1984) Changes in gonadotrophin secretion and ovarian antral follicular activity in seasonally breeding sheep throughout the year Journal of Reproduction and Fertility 70 309-321

McNeilly AS and Fraser HM (1987) Effect of gonadotrophin releasing hormone agonist induced suppression of LH and FSH on follicle growth and corpus luteum function in the ewe Journal of Endocrinology 115 273-282

McNeilly AS, Picton HM, Campbell BK and Baird DT (1991) Gonadotrophic control of follicle growth in the ewe Journal of Reproduction and Fertility Supplement 43 177-186

Mitchell LM, King ME, Aitken RP and Wallace JM (1996) Effect of mating season and body condition on ovulation, fertilization and pregnancy rates in crossbred ewes Theriogenology 45293

Mitchell LM, King ME, Aitken RP and Wallace JM (1997) Influence of lambing date on subsequent ovarian cyclicity and ovulation rate in ewes Animal Science 6575-81

Monget P and Martin GB (1997) Involvement of insulin-like growth factors in the interactions between nutrition and reproduction in female mammals Human Reproduction 12 Supplement 133-52

Montgomery GW, Scott IC and Johnstone PD (1988) Seasonal changes in ovulation rate in Coopworth ewes maintained at different liveweights Animal Reproduction Science 17 197-205

Niswender GD, Reichert LE, Jr, Midgley AR and Nalbandov AV (1969) Radioimmunoassay for bovine and ovine luteinising hormone Endocrinology 84 1166-1173

Rhind SM (1992) Nutrition: its effects on reproductive performance and its hormonal control in female sheep and goats. In Progress in Sheep and Goat Research pp 25-51 Ed. AW Speedy. CAB International, Wallingford

Robinson JE, Radford HM and Karsh FJ (1985) Seasonal changes in pulsatile luteinizing hormone (LH) secretion in the ewe: relationship of frequency of LH pulses to day length and response to estradiol negative feedback Biology of Reproduction 33 324-334

Russel AJF, Doney JM and Gunn RB (1969) Subjective assessment of body fat in live sheep Journal of Agricultural Science Cambridge 72 451-454

Scaramuzzi RJ and Radford HN (1983) Factors regulating ovulation rate in the ewe journal of Reproduction and Fertility $69353-367$

Scaramuzzi RJ, Adams NR, Baird DT et al. (1993) A model for follicle selection and the determination of ovulation rate in the ewe Reproduction Fertility and Development 5 459-478

Vipond JE (1997) May lambing: production targets. Technical Note T429 The Scottish Agricultural College

Webster GM and Haresign W (1983) Seasonal changes in LH and prolactin concentrations in ewes of two breeds Journal of Reproduction and Fertility 67 $465-471$ 
Wheeler AG and Land RB (1977) Seasonal variation in oestrus and ovarian activity of Finnish Landrace, Tasmanian Merino and Scottish Blackface ewes Animal Production 24 363-376
Zarco L, Stabenfeldt GH, Quirke JF, Kindahl $\mathrm{H}$ and Bradford GE (1988) Release of prostaglandin F-2 $\alpha$ and the timing of events associated with luteolysis in ewes with oestrous cycles of different lengths journal of Reproduction and Fertility 83 517-526 